DOI https://doi.org/10.30525/978-9934-26-182-4-4

\title{
МОЛЕКУЛЯРНО-ГЕНЕТИЧНА ДІАГНОСТИКА ВІРУСА ПАПІЛОМИ ЛЮДИНИ
}

\author{
Богдан Н. С. \\ лікар-лаборант \\ ТОВ «Медичний иентр здоров 'я» \\ м. Харків, Україна
}

Віруси папіломи людини (ВПЛ) - широко розповсюджена та дуже варіабельна група вірусів, яким властива онкогенність. Клітинамимішенями для ВПЛ є епітеліальні клітини шкіри та слизових оболонок [4]. Віруси, що відповідають за ракові захворювання слизової оболонки шийки матки, вульви, статевого члена, заднього проходу складають групу високого канцерогенного ризику $(16,18,31,33,35,39,45,52,52,56,58$, 59, 66 та 68 тип) [1,3]. При клінічній та субклінічній інфекції відмічається ріко чи слабко виражені зміни епітелію клітин. В мазках 3 поверхні епітелію виявляють койлоцити [2,3].

Для діагностики ВПЛ були використані найбільш розповсюджені види дослідження:

- мікроскопія цитологічних препаратів зішкрябу епітеліальних клітин із уретри у чоловіків, шийки матки та стінок вагіни у жінок, зафарбованих за методом Папенгейма.

- ДНК тестування.

Було обстежено 376 людей. У 51 були виявлені койлоцити в цитологічних препаратах. Усі пацієнти з позитивним результатом на наявність цитопатичних клітин були обстежені додатково методом ПЛР на наявність ВПЛ 16 та 18 типів. Всього було отримано 34 позитивних результати. Із них у двох обстежених були виявлені віруси типів 16 та 18.

Цитологічні заключення були розподілені на типи.

Цитограма 1 типу: виявлені койлоцити 3 нерівною ядерною мембраною, двоядерні клітини, багатоядерні клітини, елементи запалення. Цитограма 2 тип: виявлені койлоцити з нерівною ядерною мембраною, двоядерні клітини, елементи запалення. Цитограма 3 типу: виявлені койлоцити, двоядерні клітини, елементи запалення. Цитограма 4 типу: виявлені койлоцити, двоядерні клітини, без елементів запалення. Цитограма 5 типу: виявлені койлоцити, без елементів запалення. Цитограма 6 типу: виявлені сумнівні койлоцити. 
Необхідно відмітити, що близько 46,1\% пацієнтів мали клінічні ознаки інфікування вірусом. У результаті обстеження було виділено 2 групи пацієнтів: I група - пацієнти з цитограмою від 1 до 6 типу 3 позитивним результатом ПЛР-тесту на наявність ВПЛ 16, 18 типів; II група - пацієнти 3 цитограмою від 1 до 6 типу з негативним результатом ПЛР-тесту на наявність ВПЛ 16, 18 типів

Також всі пацієнти, що були обстежені були ще розглянуті з точки зору топографічних зон. Близько 53,1\% виявлених койлоцитів приходиться на ендоцервікс, як при інфікування лише даної зони, так і в сукупності 3 зовнішнім зівом матки, верхньо-боковим зводом вагіни. Дане явище більш йморівно пов'язано з тим, що у цервікальному каналі зона трансформації - область незрілого метаплазованого епітелію, яка розташована між плоским епітелієм екзоцервікса та циліндричним епітелієм ендоцервікса. Як відомо, незрілі клітини епітелію являються мішенню для дії вірусу.

Для більш ефективного виявленні інфікування клітин рекомендовано здійснювати комплексний забір діагностичного матеріалу шийки матки 3 обов'язковим одержанням клітин із цервікального каналу.

Можно припустити, що геніальні віруси папіломи людини із групи високого канцерогенного ризику ( 16 та 18 типи) мають свої морфологічні особливості, які виражаються в тому, що койлоцити мають більш виражену ядерну атипію.

\section{Література:}

1. Дмитриев Г.А., Глазко И.И. Диагностика инфекций, передаваемых половым путем., 2007. С. 255-265.

2. Rubin S.C., Hoskin N.J. et. al. Cervical cancer and preinvasi veneopplasia. Philadelphia: Lippincott-Raven Publishers, 2016. 482 p.

3. Титмуш Э., Адамс К. Шейка матки. Цитологический атлас / Пер. с англ.; под ред. Н.И.Кондрикова. М.: Практическая медицина, 2009. C. $107-112$.

4. Куевда Д.А., Шипулина О.Ю. Разработка и апробация тест систем для генотипирования вирусов папилломы человека высокого канцерогенного риска на основе мультипраймерной ПЦР в реальном времени // Сб. трудов 5й Всерос. науч.практ. конференции «Генодиагностика инфекционных болезней», 2004. С. 7-11. 